\title{
THE SEVENTEENTH-CENTURY DUTCH HOSPITAL IN COLOMBO
}

by

\author{
C. G. URAGODA* and K. D. PARANAVITANA'
}

Sri Lanka, known as Ceylon till 1972, is an island which was successively occupied by the Portuguese (1505-1656), the Dutch (1656-1796), and the British (1796-1948). The Portuguese and the Dutch succeeded in conquering only the maritime provinces, the central highlands being under the control of the kings of Kandy, who by force or ruse contrived to keep their kingdom intact from these two European powers. However, in 1815, the British managed also to annex the Kandyan kingdom by means of a treaty with Kandyan chiefs who had turned against their king.

In the heart of Colombo, the capital city, is an area known to this day as the Fort, which originally came within the fortifications built by the Dutch after their capture of Colombo from the Portuguese. The ramparts have since disappeared except for a tiny remnant. The land in the Fort is now the most highly priced real estate in the country and consists of only a few hectares. In this busy area is an old dilapidated and unoccupied building which was the country's leading hospital during the Dutch occupation. Few of the passers-by are aware of its identity. The narrow lane that skirts the building is known as Hospital Street, and perhaps this is the only reminder of its past. It occupies about half a hectare of land, which is a relatively large area in terms of the size of the Fort, and it is a credit to the authorities that such prime property is earmarked for restoration by the Department of Archaeology.

\section{THE BUILDING}

Paintings of the front and rear views of the Colombo hospital, done in 1771 by a Dutch artist, presumably Johannes Rach, are preserved in the Koninklijk Instituut voor Taal-, Land- en Volkekunde, Leiden (figs. 1 and 2). The building appears hardly to have changed during the past two centuries. The design is a simple one, consisting of five wings, four of which are joined to form a square with a courtyard in the centre. The fifth wing constitutes the façade of the building and is situated in front of the square with a second courtyard intervening. The only part of the hospital with an upper floor is the front wing. However, this first floor is limited in extent, and appears like a compartment sitting atop the roof in the centre of the wing (fig. 1). A wooden staircase leads to this storey, which now has the appearance of a small hall. Its floor is made of wooden planks.

As with other old Dutch buildings in Sri Lanka, the walls are over $50 \mathrm{~cm}$. thick and ${ }^{*}$ C. G. Uragoda, MD, FRCP, FCCP, AFOM, Physician-in-Charge, Central Chest Clinic, 386 Deans Road, Colombo 10, Sri Lanka.

†K. D. Paranavitana, BA, Middelbaar Archief Diploma (Netherlands), Assistant Director, Sri Lanka National Archives, 7 Reid Avenue, Colombo 7, Sri Lanka. 


\section{The seventeenth-century Dutch hospital in Colombo}

the teak beams are massive both in girth and length. These features of solid construction have undoubtedly ensured the survival of the building. A long and wide open verandah runs along the length of each wing, and is another characteristic of old Dutch architecture in the tropics. The high walls, large windows, and spacious verandahs provide a comfortable environment within, in contrast to the humid heat outside.

The courtyards which appear bare in the painting are now overgrown with vegetation, while the ornamental shrubs that formed a prominent feature against the rear windows in 1771 are no longer present. A canal which ran by one side of the building has long since disappeared, and its only memorial is the name of a narrow lane that passes one side of the building, Canal Row. It may be mentioned that the Dutch were adept at building canals in and near Colombo for transport. While some of these canals still exist outside Colombo, those within the Fort were filled up by the British soon after the capture of the city, and some of them are now busy motorways.

\section{LOCATION}

The Portuguese, who preceded the Dutch, had their hospital on another site in the Fort about half a kilometre away. Its situation by the Colombo harbour would have afforded convenience of transfer of patients from ship to hospital. This site is depicted in two maps drawn in $1656,{ }^{1}$ the year of the capitulation of Colombo to the Dutch after a siege lasting seven months and continuous bombardment that destroyed most of the buildings. Shortly after gaining control of the city, the Dutch commander-in-chief replanned it by demolishing all buildings that had been left standing. ${ }^{2}$ Probably the Portuguese hospital too was demolished in the process, for there is no subsequent record of a hospital at the original site.

The Dutch hospital was probably built shortly afterwards, but a definitive date is not available. A Dutch map drawn in 1732 shows the hospital on its present site ${ }^{3}$ and a description by a German, Christopher Schweitzer, who was in Sri Lanka from 1676 to 1682 in the service of the Dutch, implies that it was already there in 1681.4

\section{OBJECTIVES}

Considerable information on the Dutch hospital in Colombo is available from archival sources. The Sri Lanka National Archives (SLNA) are in possession of a large number of manuscripts from the Dutch period. English translations of some of these, including the memoirs of Dutch governors left for the benefit of their immediate successors, have been published from time to time, and these provide useful references to the hospital. However, in the presentation of this paper several previously unknown Dutch manuscripts dealing exclusively with the Colombo and other hospitals were traced. These documents, which were written in the archaic Dutch used at the time, have supplied considerable information on the objectives of the hospital, its administration, and other matters pertaining to it.

${ }^{1}$ R. L. Brohier and J. H. O. Paulusz, Land, maps and surveys, vol.2, Colombo, Ceylon Government Press, 1951, p.67 and plates 28 and 29.

'Ibid., p. 68.

sibid., map no. 23.

${ }^{4}$ R. Raven-Hart, Germans in Dutch Ceylon, Colombo National Museum, [n.d.], p. 78. 


\section{G. Uragoda and K. D. Paranavitana}

The declared intention of the Dutch in establishing the Colombo hospital, as well as other hospitals in the maritime provinces, was to look after the health of the officers and other staff serving under the Dutch East India Company. The preamble to the instructions issued to the steward of the hospital states that "it has been considered that it is a duty of the Company to restore the health of its officers who are on board ships as well as in the outposts". ${ }^{5}$ In a memorandum submitted to the Political Council by Jacobus de la Haije, it is stated that "its [the Company's] invalid officers could be brought back to their former state of health with the blessings of the God only by way of good care and attention, therefore it is necessary to issue clear instructions to the senior surgeons who are in the service of the Company in the country to perform their duties diligently". ${ }^{\circ}$

Holland was a leading seafaring nation at the time, and Colombo a busy port where special provision had to be made for the sick brought in by ships. The Company intended to provide a sufficiently large hospital in Colombo to cater for the local Dutch population as well as the floating population. The influx from ships would have been considerable, as sickness was rife during long sea voyages. The British, who succeeded the Dutch, had similar provisions in their hospitals in Colombo for the benefit of those who fell ill at sea. Till recent times, the General Hospital, Colombo, maintained a seamen's ward.

\section{ADMINISTRATION}

The Dutch East India Company was formed in Amsterdam in 1602. At the time, the sovereignty of Holland rested with the States General (Staten Generaal), which was composed of representatives from each of the seven provinces. It, in turn, granted the Company powers of sovereignty over Dutch possessions in the east including Sri Lanka. It was a large trading company that was vested with military powers to enable it to pursue its policies aggressively. The eastern headquarters of the Company were in Batavia (now Djakarta), the capital of the Dutch East Indies. Sri Lanka was governed by a resident governor who was answerable to the High Government of India in Batavia, the reference here being to the Dutch East Indies and not to present-day India. The governor administered the country through a Political Council, which was equivalent to a cabinet of ministers.

Policy regarding the administration of the Colombo hospital, as well as other hospitals in the country, was laid down by the Political Council, but occasionally the more important matters were referred to Batavia for decision. Examples are preserved in the archives at The Hague and Colombo. In a set of regulations laid down by the High Government in Batavia, the medical superintendent or chief surgeon was made responsible for the internal administration of the hospital. ${ }^{7}$ It was the policy of the Dutch to have a board of regents for each hospital, consisting of two or three persons who were unconnected with the hospital. The necessity for such appointments was clearly enunciated by Zwaardecroon: "this [hospital] is a place

\footnotetext{
${ }^{5}$ Sri Lanka National Archives (hereinafter SLNA) 1/2453, minutes of the Dutch Political Council (PC), dated 1 February 1669.

${ }^{6}$ SLNA $1 / 18$, PC, dated 22 July 1672.

'Jos Maseland, 'Restoration of the VOC hospital in Colombo', unpublished dissertation, Delft, 1982.
} 


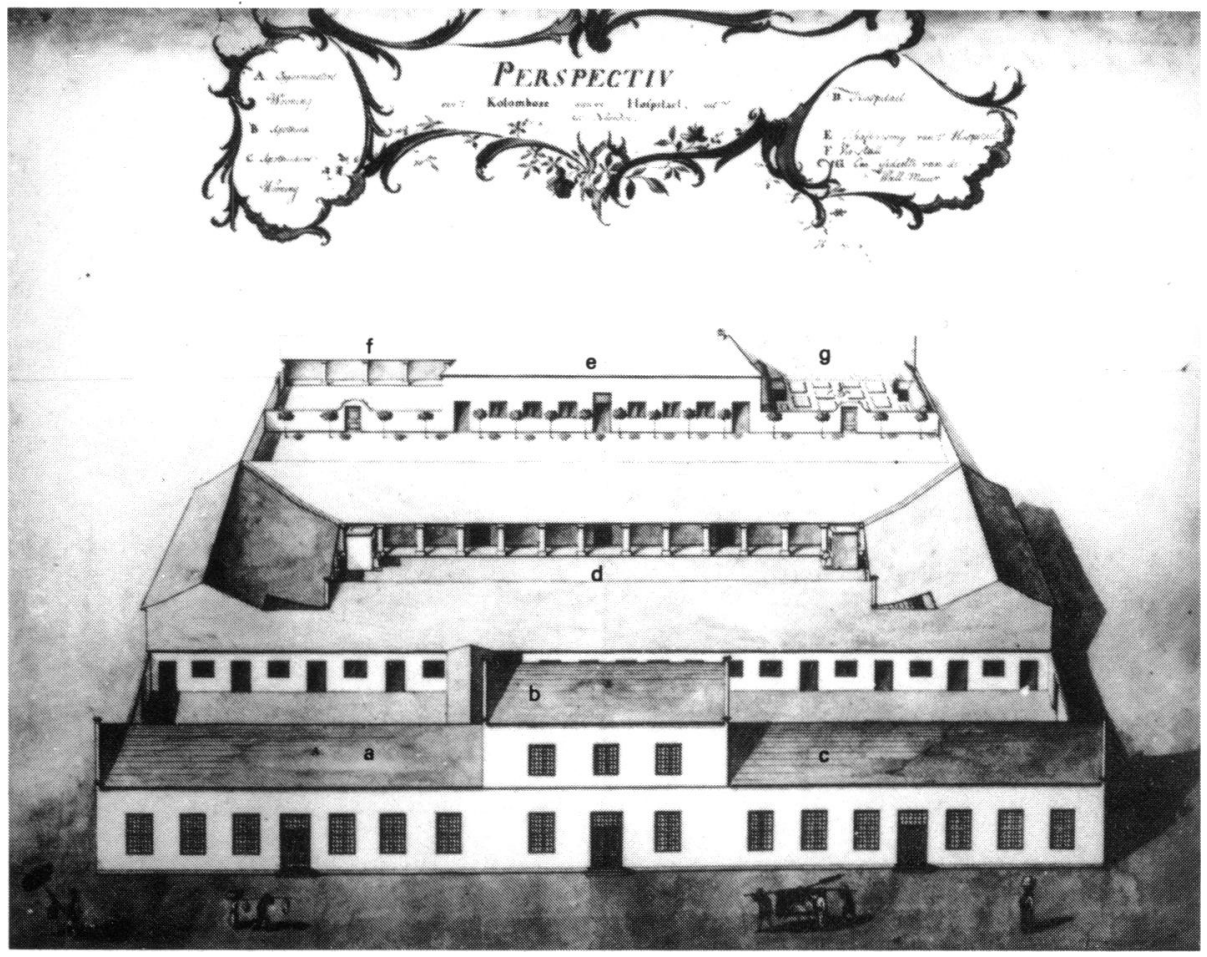

Figure 1. Front view of the Dutch hospital in Colombo. Painting presumably by Johannes Rach, 1771 . Koninklijk Instituut voor Taal-, Land- en Volkenkunde, Leiden. A. chief surgeon's residence; B. pharmacy; C. apothecary's residence; D. hospital; E. kitchen; F. cattle shed; G. wall.
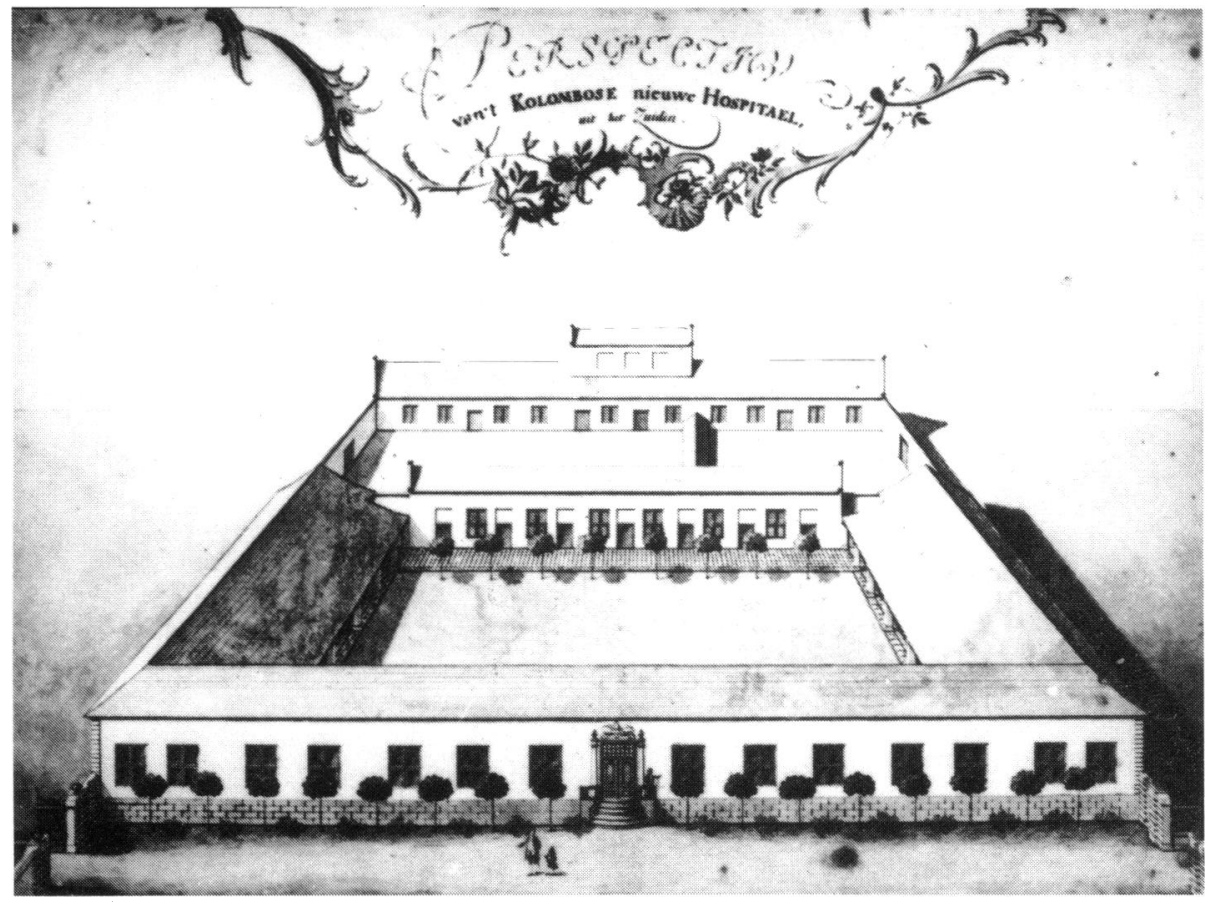

Figure 2. Rear view of the Dutch hospital in Colombo. Painting presumably by Johannes Rach, 1771 . Koninklijk Instituut voor Taal-, Land- en Volkenkunde, Leiden. 


\title{
The seventeenth-century Dutch hospital in Colombo
}

where the Company shows its sympathy with its suffering servants and wishes them to have every comfort. For this reason also regents are appointed to see that nothing wrong is done by the doctor or the steward." In the Colombo hospital, the regents included the military commander and the officer in charge of the stores. ${ }^{9}$

\section{MEDICAL STAFF}

The medical staff of the Colombo hospital in the final years of Dutch occupation consisted of the chief surgeon (on a salary of 60 guilders a month), one surgeon (30 guilders), three junior surgeons (22 to 24 guilders), three third surgeons (14 guilders), and five interns (9 guilders). ${ }^{10}$ The higher-grade surgeons were generally graduates from Amsterdam, Utrecht, and Leiden. ${ }^{11}$ It was not uncommon for ships' surgeons to be appointed to the hospital, and there was no strict rule that only qualified graduates could be appointed as surgeons. C. F. Reimer, for example, was a private soldier, and when it was discovered that he had sufficient medical skill, he was sent to Sri Lanka in October 1768 as a third surgeon..$^{12}$ Incidentally, he was also a painter, and he captured on canvas the historic occasion when Governor Flack and the Kandyan ambassadors signed a treaty. ${ }^{13}$

The surgeon with the longest service at the Colombo hospital was Alleman. He served the hospital for nearly a third of the period of Dutch occupation (1756 until at least 1790). He was first appointed by the Political Council by a resolution dated 9 October 1756: "Considering the old age of the chief surgeon, Dirk Berghuis, and the acute need of a qualified assistant, it has been decided to appoint the chief surgeon of the ship "Gheisenberg", Barend Alleman van Ligtenvoord as the second surgeon in the Dutch hospital in Colombo". ${ }^{14}$ Alleman wrote frequent memoranda to the Political Council about the deficiencies in the hospital, and through his efforts many improvements were effected.*

The most famous of all the surgeons who worked in the Colombo hospital was undoubtedly Paul Hermann, who has been described as the father of botany in Sri

\footnotetext{
${ }^{8}$ Hendrick Zwaardecroon, Memoir of Hendrick Zwaardecroon, commander of Jaffnapatam (afterwards governor-general of Nederlands India), 1697, trans. by Sophia Pieters, Colombo, Government Printer, 1911, p. 78.

${ }^{9}$ Maseland, op. cit., note 7 above.

${ }^{10}$ Ibid.

${ }^{11}$ E. L. Koch, 'A sketch of the medical history of Ceylon',Journal of the Dutch Burgher Union of Ceylon, 1946, 35: 74-84.

${ }^{12} \mathrm{~J}$. H. O. Paulusz, 'Dutch painting of Kandyan embassy', Journal of the Ceylon Branch of the Royal Asiatic Society, 1953, 3 (new series): 70-71.

${ }^{13}$ P. E. Pieris, 'A Dutch painting, 1766', ibid., 1948, 38: 22-23.

${ }^{14}$ SLNA 1/288, PC, dated 9 October 1756.
}

\begin{abstract}
*Throughout his long service, Alleman strove to improve the lot of the patients. When, by resolutions of the Political Council dated 12 May and 10 July 1786, the vote on provisions for the hospital was reduced, Alleman appealed successfully for a revision. The vote on medicines and linen was doubled, and increased quantities of wine, oats, sago, butter, powdered sugar, and wheat flour were allowed to the patients. They were also provided with a rupee a month each, deductible from their salaries, for the purchase of such items as sugar, tea, and tobacco (SLNA 1/202, PC, dated 7 August 1788). The very ill patients were provided with a mattress (ibid.), while the others had only a mat (Maseland, op. cit., note 7 above). Patients who did not have a change of clothing were given a shirt, long trousers, and a jacket, all made of rough linen from Tuticorin in South India (a Dutch possession governed from Sri Lanka) (SLNA 1/18, op. cit., note 6 above; Maseland, op. cit., note 7 above).
\end{abstract}




\section{G. Uragoda and K. D. Paranavitana}

Lanka. ${ }^{15} \mathrm{He}$ was attached to the Colombo hospital from 1672 to 1679 . His main interest was botany, and, except for three plants, all the others he saw in Sri Lanka were new to him. He sent collections of local plants to Leiden, and a herbarium he collected in Sri Lanka came to light about seventy years after his death. Linnaeus classified 429 out of the 657 specimens and published the work under the name Flora zeylanica,${ }^{16}$ describing Hermann as the prince of botanists. ${ }^{17}$ While in Sri Lanka, Hermann was offered the chair of botany at Leiden, which he took up in 1680. Although he was acknowledged as a distinguished botanist, he was most unpopular with his patients and subordinates. Schweitzer wrote: "The Chief Inspector that had the care of it [the hospital] in my time was Dr. Hermannus, now Professor of Medicine [sic] at Leyden. He took no good praise away with him from the soldiers and seamen that came under his hands. He was a true tyrant over his slaves, with blows and whippings; he was also accused of killing a female slave whom he let bury [sic] in the garden behind his house, and was for some days under arrest in his house, but was after set free."18

Another botanist of repute who worked as a surgeon in Colombo was Nicholas Grimm, a Swedish doctor who came to Sri Lanka in 1674 and worked under Hermann, and who also wrote a book on Sri Lankan plants.

The chief surgeon of the hospital was not a member of the Political Council, which was composed of high-ranking military and civil officers. However, he came fairly high in the order of precedence observed at important social functions. At the funeral procession of Robertus Cramer, merchant, ${ }^{19}$ the chief surgeon Dirk Berghuys walked in the twentieth place behind the governor. Alleman, who was second surgeon at the time, walked another sixteen places behind.

The duty of the surgeons was mainly to visit the hospital twice a day, but they were obliged to call on patients in their homes on request, provided these domiciliary visits did not interfere with their hospital routine.$^{20} \mathrm{~A}$ visit of this nature was recorded by the Englishman, Robert Knox, who was held captive by the king of Kandy for twenty years. In 1679, he, along with one of his fellow-prisoners, managed to escape into Dutch territory. On their arrival in Colombo, the companion developed fever (probably malaria). Knox wrote: "My consort's ague increased and grew very bad; but the chief chirurgeon by order daily came to see him, and gave him such potions of physick, that by God's blessing he soon after recovered."21

On special occasions, a surgeon from Colombo was sent over long distances on politically important professional missions, for example, the despatch of Dr Danielsz in 1739 to Kandy at the request of King Rajasinghe, who was suffering from an ulcer in the leg. Danielsz was obliged to beat a hasty retreat to escape the wrath of his royal patient, who disapproved of his treatment. ${ }^{22}$

${ }^{15}$ Edmund Peiris, 'Paul Hermann, the father of Ceylon botany', Journal of the Ceylon Branch of the Royal Asiatic Society, 1952, 2 (new seies): 1-20.

${ }^{16}$ Edmund Peiris, 'Studies in medical herbaria', Trans. Ceylon Coll. Physns, 1973, 6: 97-107.

${ }^{17}$ Peiris, op. cit., note 15 above.

${ }^{18}$ Raven-Hart, op. cit., note 4 above, p. 78

${ }^{19} \mathrm{~F}$. H. de Vos, 'Three funerals of Ceylon Dutch officials in the eighteenth century', Journal of the Ceylon Branch of the Royal Asiatic Society, 1903, 18: 100-129.

${ }^{20}$ SLNA 1/18, op. cit., note 6 above.

${ }^{21}$ Robert Knox, An historical relation of Ceylon, Maharagama, Ceylon, Saman Press, 1958, p. 278. First published in London in 1681, this book was the first to have been written in English on Sri Lanka. 


\section{The seventeenth-century Dutch hospital in Colombo}

Junior surgeons were on call at all hours of the night, except those who were married and living outside the city. Unmarried junior surgeons were expected to live close to the hospital so that they were easily available in case of an emergency. ${ }^{23}$

The hospital had on its staff an apothecary, who worked under the medical superintendent and was responsible for the dispensing of medicines according to an approved pharmacopoeia. In 1786, Allemann recommended that separate quarters be provided for the apothecary and his dispensary. In response, the Political Council decided to construct or convert a suitable building for the purpose. ${ }^{24}$

\section{NON-MEDICAL STAFF}

Very early in the Dutch occupation, the Political Council appointed a steward to the Colombo hospital. "The Company considers it one of its duties to restore the health of its officers on board ships and its outposts; therefore the Company decided to appoint and pay a steward who should be attached to the Colombo hospital." ${ }^{25}$ His administrative duties were second in importance to those of the medical superintendent. He was responsible for the purchase of provisions and the supply of meals to patients. For this purpose, he was provided with a fixed sum of money per patient. A meal for an ordinary patient included a beef soup and a dessert. Special diets containing such items as gruel, milk, chicken soup, sago, and warm soft drinks were provided to more seriously ill patients on the recommendation of the surgeons. ${ }^{28}$ The steward was also expected to see to the cleanliness of the hospital and the patients. ${ }^{27}$

The other members of the non-medical staff were a cook, porter, laundryman, and several slaves. The cook and porter were Europeans ${ }^{28}$ while the laundryman was always a native of Sri Lanka. The cook's salary was $\mathbf{2 4}$ guilders a month, which was on a par with that of a junior surgeon. The porter, usually an ex-serviceman, received 14 guilders compared to only 9 for an intern. ${ }^{20}$ One of his duties was to see that patients did not sneak out for a drink, but there were several instances of negligence of duty in this respect..$^{30}$ The hospital was served by one laundryman till 1787, when an extra hand was appointed on a recommendation by Alleman. ${ }^{31}$

There is no indication that the hospital was served by nurses, male or female. In fact, till recent times, there were hospitals of moderate size in Sri Lanka where patients were served by a category of workers known as attendants who had no training as nurses. The nursing duties in the Dutch hospital were probably shared by junior surgeons, interns, and the steward, while the slaves did the work that did not require special training.

\footnotetext{
${ }^{22}$ SLNA $1 / 3289$, dated 10 May 1739 . 'Diary kept by Dr. Danielsz of his journey to Kandy to cure the king'.

${ }^{23}$ SLNA $1 / 18$, op. cit., note 6 above.

"SLNA 1/193, PC, dated 2 March 1786.

${ }^{25}$ SLNA 1/2453, PC, dated 1 February 1669.

${ }^{26}$ Maseland, op. cit., note 7 above.

${ }^{27}$ SLNA 1/18, op. cit., note 6 above.

${ }^{28}$ SLNA 1/120, PC, dated 21 May 1757.

${ }^{20}$ Maseland, op. cit., note 7 above.

${ }^{30}$ SLNA $1 / 18$, op. cit., note 6 above.

${ }^{31}$ SLNA 1/198, PC, dated 19 October 1787.
} 


\section{G. Uragoda and K. D. Paranavitana}

\section{DISEASES}

A general hospital catering to a large military and sea-faring population in the seventeenth and eighteenth centuries would have had to deal with various injuries, including fractures. Diseases of a medical nature which were frequently treated at the hospital included dropsy, epilepsy, colds, diarrhoea, fever, scabies, and venereal ailments. ${ }^{32}$ Foreigners occupying Sri Lanka were subject to a host of diseases, some of which affected them more severely than the local population. Soldiers on campaigns outside Colombo developed dysentery, sometimes in epidemic proportions, and were admitted to hospital. ${ }^{33}$ The leech, which abounded in Kandyan areas, was an enemy of the foreign soldier on the march and an ally of the defending Kandyans. Leech bites sometimes developed into maggot-infested ulcers, which resulted in loss of limb or life.$^{34}$ Malaria was a problem outside Colombo. The Dutch had a morbid fear of leprosy. In 1685, the chief surgeon drew the attention of the authorities to the alarming prevalence of leprosy among the children of the Dutch by their native wives. As a result, a separate hospital for lepers was built in 1708 a few kilometres from Colombo. ${ }^{35}$

Special consideration was given to venereal diseases. Schweitzer saw many soldiers in the Colombo hospital "who in pursuit of their lustful desires destroy themselves by venereal distempers". ${ }^{36}$ It was perhaps the only condition for which a surgeon from the Colombo hospital was paid a gratuity for successfully treating a patient. ${ }^{36}$

\section{MEDICINES}

Most of the medicines used in the hospital were imported from Europe and other countries, ${ }^{37}$ while the rest, such as spices, were obtained locally. Opium, for example, was brought from Surat, one of the Dutch possessions in India. ${ }^{38}$

A close check was kept on the medicines, which were kept locked up in special medicine boxes. These boxes were probably imported from Amsterdam at first, ${ }^{39}$ but later produced locally. ${ }^{40}$ Their keys were kept by the doctor, and without his presence no one was allowed access to them. When the apothecary required some medicine, he had to go with the doctor to the warehouse to open the chests and fetch it. All such issues were carefully entered in books which showed the stock in hand and the amount consumed. ${ }^{41}$

\footnotetext{
${ }^{32}$ Maseland, op. cit., note 7 above.

${ }^{33} \mathrm{John}$ Davy, An account of the interior of Ceylon and of its inhabitants with travels in that island, Dehiwela, Ceylon, Tisara Prakasakayo, 1969,-pp. 361-363; H. Marshall, Notes on the medical topography of the interior of Ceylon, London, Adam Black, 1821.

${ }^{34}$ C. G. Uragoda, 'Some historical aspects of dermatology in Sri Lanka', Int. J. Dermatol., 1984, (in press).

${ }^{35}$ C. de F. W. Goonaratna, 'Some historical aspects of leprosy in Ceylon during the Dutch period 1658-1796', Med. Hist., 1971, 15: 68-78.

${ }^{36}$ Raven-Hart, op. cit., note 4 above, p. 49; SLNA 1/202, PC, dated 7 August 1788.

${ }^{37}$ SLNA 1/18, op. cit., note 6 above.

${ }^{38}$ C. G. Uragoda, 'History of opium in Sri Lanka', Med. Hist., 1983, 27: 69-76.

${ }^{39}$ Maseland, op. cit., note 7 above.

${ }^{40}$ Julius Stein Van Gollenesse, Selections from the Dutch records of the government of Sri Lanka; Memoir of Julius Stein Van Gollenesse, governor of Ceylon, 1743-1751, trans. by Sinnappah Arasaratnam, Colombo, Department of National Archives, 1974, p. 90.

${ }^{41}$ SLNA 1/18, op. cit., note 6 above.
} 


\section{The seventeenth-century Dutch hospital in Colombo}

The apothecary dispensed the medicines according to a pharmacopoeia approved by the Political Council and listed in its entirety in the minutes of $18 \mathrm{June} 1757 .{ }^{42}$ This pharmacopoeia was still in use in $1790 .{ }^{43}$ The local drugs that were used were mainly spices, such as cinnamon, ginger, and cardamon. It may be mentioned that one of the major attractions that induced the Dutch to conquer Sri Lanka was the availability of spices there. Cinnamon, for example, was grown only in Sri Lanka. ${ }^{44}$ Coriander, well known as a diaphoretic in ayurvedic medicine, was another item that figured in the Dutch pharmacopoeia.

Towards the latter part of their rule, the Dutch began to appreciate and make use of the superior knowledge of herbal medicines possessed by the local ayurvedic physicians. In 1793, they adopted a far-reaching resolution in the Political Council whereby a "native" physician was appointed to each of the Dutch hospitals in Sri Lanka. His duty was to assist the chief surgeon in the daily visits to the sick so that his knowledge was utilized in the best manner. ${ }^{45}$

Drugs from the hospital were sometimes sold, but the hospital authorities were prohibited from donating or disposing of them in any other manner. ${ }^{46}$ Ships which called at Colombo sometimes requested medicines. The Political Council had to approve such issues, as is implied by a resolution based on a request from the ship Vreedenburg. ${ }^{47}$ Rules were strictly enforced with regard to drugs. Apothecary Strasburg, for example, had to obtain special permission in 1790 to write off certain medicines prepared according to the 1757 pharmacopoeia. ${ }^{48}$

The hospital provided wine and liquor for medicinal purposes. Cape wine or "vinetint" was popular as a tonic for patients with diarrhoea ${ }^{49}$ Liquor given to patients included arrack, which was a local drink distilled from the sap of the coconut flower. Patients were prohibited from taking alcohol except for medical indications. As drunkenness was common among the patients, they were not allowed to leavehospital at night, and liquor smuggled by patients into the hospital premises was liable to confiscation. ${ }^{50}$

\section{ACCOMMODATION}

The Colombo hospital was the largest in Sri Lanka at the time, for Colombo had the highest Dutch population in the country, consisting of the military personnel, civilians such as the merchants, and the seafarers who frequented the busy port. The military personnel numbered 2,966 in 1700, 4,652 in 1753, and 3,784 in 1780 in Sri

\footnotetext{
${ }^{42}$ SLNA 1/21, PC, dated 18 June 1757.

${ }^{43}$ SLNA $1 / 208$, PC, dated 12 March 1790.

${ }^{44}$ C. G. Uragoda, 'Asthma and other symptoms in cinnamon workers', Br. J. ind. Med., 1984, 41: 224-227.

${ }^{45} \mathrm{D}$. A. Kotelawele, 'Some notes on the Dutch interest in native medicine in Sri Lanka', Journal of the Netherland Alumni Association of Lanka, 1982, special issue, pp. 23-25; SLNA 1/1342, PC, dated 2 November 1793 and 25 January 1794.

${ }^{46}$ SLNA $1 / 18$, op. cit., note 6 above.

${ }^{47}$ SLNA 1/208, PC, dated 27 February 1790.

${ }^{48}$ SLNA $1 / 208$, op. cit., note 43 above.

${ }^{49}$ SLNA 1/202, PC, dated 7 August 1788.

${ }^{50}$ Maseland, op. cit., note 7 above.
} 


\section{G. Uragoda and K. D. Paranavitana}

Lanka; compared to Batavia, which had 3,853, 4,860, and 3,283 respectively. ${ }^{51}$ Such a population required a large hospital.

In 1785 , there was accommodation for only 180 patients, and in October of that year all the wards were full and patients were admitted on a first come first served basis. ${ }^{52}$ Alleman made a strong plea for reconstruction on the basis of insufficient accommodation as well as other grounds. The chief surgeon's quarters were used as a residence-cum-storehouse during both the Dutch and early British periods, causing Alleman to complain to the Political Council in 1785 that his quarters were not spacious enough to house the hospital stores. The Political Council in 1786 decided to enlarge and improve the hospital and to construct or convert a suitable building for the apothecary and his dispensary. ${ }^{53}$ The hospital was then able to take in 300 patients.

The limitation on numbers probably did not apply during epidemics and emergencies. Schweitzer, while referring to dysentery, reported that in 1676 he saw more soldiers in hospital than in the garrison. ${ }^{54}$

The hospital was a fee-levying institution. The Company deducted half the salary in lieu of hospital dues, and a further sum for linen, pillows, and a mattress, according to the requirements of the patient. ${ }^{55}$ It was unlikely that non-Europeans were admitted. In any case, the fee-levying character of the hospital would have effectively barred them, for only a few could have afforded such fees.

The slaves, although employees of the Dutch East India Company, were denied admission to the hospital. The Dutch and the Portuguese brought to Sri Lanka many Negro slaves from their possessions in Africa. They introduced at least one new disease, yaws, to the country. ${ }^{56}$ It would have been unthinkable in those days for slaves to have been treated in the same hospital as their masters. In 1707, Governor Joan Simons completed a special hospital for these slaves. ${ }^{57}$ It was situated in the slaves' quarters outside the Rotterdam gate of the city, and had its own doctor. On representation from the surgeon, Johannes Schoorman, in 1757, the number of public houses in the area was reduced to one in order to limit drunkenness and sickness among the slaves. ${ }^{58}$

The Colombo hospital was in acute need of repairs in the latter part of the eighteenth century. According to the account books maintained by the Company, a total of 66,031 guilders were spent on this work from 1764 to $1773{ }^{39}$ Still, there were several shortcomings apart from the lack of accommodation already referred to. Only one well was situated in the premises, and the water was not sufficient to wash

\footnotetext{
${ }^{51}$ E. van den Boogaart, et al., Overzee Nederlandse koloniale geschiedenis 1590-1975, Haarlem, Fibula-Van Dischoeck, 1982, p. 78.

s2 SLNA 1/193, PC, dated 12 December 1785.

${ }^{53}$ SLNA 1/193, op. cit., note 24 above.

${ }^{34}$ Raven-Hart, op. cit., note 4 above, p. 49.

${ }^{5 s}$ Maseland, op. cit., note 7 above.

${ }^{56}$ Uragoda, op. cit., note 34 above.

${ }^{57}$ Cornelius Joan Simons, Memoir of Cornelius Joan Simons, governor and director of Ceylon for his successor Hendrick Becker, 1707, trans. by Sophia Anthonisz, Colombo, Government Printer, 1914, p. 25.

${ }^{58}$ SLNA 1/121, PC, dated 18 June 1757.

${ }^{59}$ Maseland, op. cit., note 7 above.
} 


\section{The seventeenth-century Dutch hospital in Colombo}

the lavatories. Smells emanating from the open lavatories were a nuisance to the inmates. The washing-room was not provided with its own well, as digging such a well would have endangered the adjoining building. The situation was made worse during the dry season when extra expenditure had to be incurred in procuring buckets of water from nearby wells. ${ }^{60}$

\section{DISCIPLINE}

The Colombo hospital was run according to a set of rules laid down by the Company ${ }^{61}$ All sick officers of the Company were entitled to admission at their own request. They were not expected to seek treatment elsewhere without permission from the regents. Guests of the officers were not allowed to use the hospital as lodgings for the night. Patients were admitted on the understanding that they undertook to observe the rules of the hospital.

Misdemeanours by the staff or the patients were dealt with at one of three levels, namely courts of justice, the regents, and the medical superintendent, depending on their gravity. Gambling, abusive behaviour, noise-making and disturbing other patients, sneaking out of the hospital, throwing food through windows, or straying into the precincts of the canal just outside the hospital were prohibited. Any officer or attendant found sleeping or missing from hospital while on duty was liable to be punished with fifty strokes. Patients who caused injury to others were charged before the courts. At the time of the surgeons' visits to the wards, all patients were expected to be in their respective places. Patients were not allowed to bring their own fruits, sweets, or other food without permission.

The code of conduct outlined here was laid down in 1790 and probably reflected over 130 years of experience in running the hospital. It was undoubtedly an attempt to curb the recurrence of undesirable incidents that had created problems in the past.

\section{REPUTATION OF THE HOSPITAL}

The Colombo hospital enjoyed a good reputation, which is vouched for by more than one writer during Dutch times. Heydt, a German who took employment under the Dutch East India Company, was in Sri Lanka from 1734 to 1737. In a book of his travels published in $\mathbf{1 7 7 4}$ he wrote:

\footnotetext{
While I write of Colombo, I must mention its hospital. I have already mentioned in my earlier pages concerning Batavia the bad arrangements of the hospital there, but here the conditions are very different. I think the Company has no better hospital in all the Indies than here in Colombo, since here various and costly medicines are prepared, and there is a doctor to be found, provided with a good laboratory, together with three assistants who are experienced in medicines. The Company allots to them many slaves to serve the sick, and there is a ward-master, who commands both the sick and the slaves. The rest of the arrangement is not less well ordered, since each patient has an under-bed, two pillows and a chintz mattress, and receives two meals a day; and he can without hesitation ask for what he will; since each morning the cook goes to the patients with a list of food and asks what he wishes to eat. Then when the food is ready, the black boys come and take it, prepared in heavy bowls of beaten iron, on a board four or five feet long, and go into one or other of the wards. But of rice, pepper, vinegar, salt and such like each may have as much as he asks. From which can be seen how much trouble, care and solicitude is given to the sick..$^{62}$
}

${ }^{60}$ SLNA 1/193, op. cit., note 52 above.

${ }^{61}$ Maseland, op. cit., note 7 above. 


\section{G. Uragoda and K. D. Paranavitana}

Another German who praised the hospital was Christopher Schweitzer: "There is a well built hospital in which the sick Dutchmen are laid and well served by surgeons and slaves with medicants and plaisters."

The British, who succeeded the Dutch in 1796, continued to use the building for some time as a hospital. Captain Robert Percival came to Sri Lanka in that year, and stayed for three years. His account of the country published in 1803 was perhaps the earliest by a British writer. He wrote:

The hospital which is designed for soldiers and sailors is roomy and convenient. It is very properly divided into distinct wards, so as to keep the sick of different disorders completely separate, and thus prevent infection from spreading. Close by it is a house for the chief surgeon, where all the hospital stores are prepared and kept. It is with much pleasure $I$ add, that this hospital, (an institution so indispensably necessary in these hot climates) is extremely well managed; and that every attention is paid to the health of the troops who are sent here for medical attention. ${ }^{\text {st }}$

The separation of the hospital into wards was commented on by both Heydt and Percival, though under two different administrations.

\footnotetext{
62 Johann Wolfgang Heydt, Heydt's Ceylon, trans. by R. Raven-Hart, Colombo, Ceylon Government Information Department, 1952, p. 3.

${ }^{63}$ Raven-Hart, op. cit., note 4 above.

4 Robert Percival, An account of the island of Ceylon, Dehiwala, Sri Lanka, Tisara Prakasakayo, 1975, p. 84.
} 